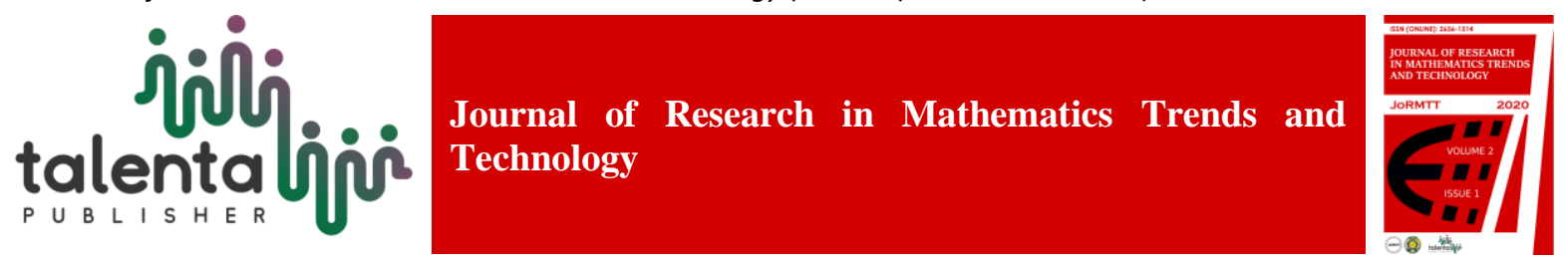

\title{
Monte Carlo Simulation Approach to Determine the Optimal Solution of Probabilistic Supply Cost
}

\author{
Helmi Ramadan ${ }^{1 *}$, Prana Ugiana Gio ${ }^{1}$, Elly Rosmaini ${ }^{1}$ \\ ${ }^{1}$ Department of Mathematics, Universitas Sumatera Utara, Medan, 20155, Indonesia
}

\begin{abstract}
Monte Carlo simulation is a probabilistic simulation where the solution of problem is given based on random process. The random process involves a probability distribution from data variable collected based on historical data. The used model is probabilistic Economic Order Quantity Model (EOQ). This model then assumed use Monte Carlo simulation, so that obtained the total of optimal supply cost in the future. Based on data processing, the result of probabilistic EOQ is $\$ 486128,19$. After simulation using Monte Carlo simulation where the demand data follows normal distribution and it is obtained the total of supply cost is $\$ 46116,05$ in 23 months later. Whereas the demand data uses Weibull distribution is obtained the total of supply stock is $\$ 482301,76$. So that, Monte Carlo simulation can calculate the total of optimal supply in the future based on historical demand data.
\end{abstract}

Keyword: EOQ Model, Monte Carlo simulation

\begin{abstract}
Abstrak. Simulasi Monte Carlo merupakan suatu simulasi probabilistic dimana solusi dari permasalahannya diberikan berdasarkan proses acak. Proses acak melibatkan distribusi probabilitas dari variable data yang diperoleh dari data yang lalu. Model yang digunakan adalah model probabilistik Economic Order Quantity (EOQ). Model ini kemudian diasumsikan menggunakan simulasi Monte Carlo, sehingga diperoleh total dari biaya pemasokan yang optimal pada masa yang akan datang. Berdasarkan pemrosesan data, hasil dari probabilistik EOQ adalah $\$ 486128,19$. Setelah menggunakan simulasi Monte Carlo dimana data permintaan mengikuti distribusi normal dan diperoleh total biaya pemasokan adalah \$46116,05 pada 23 bulan kemudian. Ketika data permintaan menggunakan distribusi Weibull, diperoleh total stok pemasokan adalah \$482301,76. Sehingga, simulasi Monte Carlo dapat menghitung total pemasokan optimal pada masa yang akan datang berdasarkan data permintaan yang lalu.
\end{abstract}

Kata Kunci: Model EOQ, Simulasi Monte Carlo

Received 2 December 2019 | Revised 5 January 2020 | Accepted 15 February 2020

\section{Introduction}

Simulation is a numerical technique to do an experiment in computer involving a certain mathematical and logical model displaying business characteristic and economic system in a

*Corresponding author at: Department of Mathematics, Universitas Sumatera Utara, Medan, 20155, Indonesia 
long time period [1]. Vita [2] simulation is a tool to analyze the inventory system where a demand is a random variable reflecting an uncertain demand. A survey conducted in 1978 by The Institute Management Science (TIMS) and The Operations Research Society of America (ORSA) in America informs that a simulation on the third rank after analysis of economics and statistics.

This information states that a simulation is a tool or method that can be used to solve the problem and give a solution. The reliability of simulation can face the complex problem, measure a performance from a various data and give the alternative solution quickly using computer program. One of simulation model is Monte Carlo simulation. Djati [3] stating that a Monte Carlo simulation will give an indication of several inventory that must be at store and when the order conducted.

\section{Research Methodology}

Monte Carlo simulation is a pattern using random number, namely random variable $U(0,1)$ used to solve stochastic and deterministic problem, the time does not play the real role. Generally the Monte Carlo simulation is more static rather than dynamic. Monte Carlo simulation involves the random number. Render, et al., [4] there are 5 steps to perform a simulation, namely:

1. Define a known probability distribution based on historical data.

2. Build a cumulative probability distribution for each variable.

3. Perform a simulation to generate random number.

4. The result from analysis or output is used as an input and evaluation.

5. Do this simulation repeatedly.

Random number is an arbitrary number and have a criteria that must be fulfilled, namely:

1. Random number has uniform disribution.

2. Each number is independent.

Random number is symbolized with $U$ and these values are between 0 and 1 , and can be stated $\mathrm{U}(0,1)$. Various way to obtain random number can with computer random number table or use the random number method. One of method to generate random number is Linear Congruental Generator (LCG). LCG has formula as follows.

$$
Z_{i}=\left(a Z_{i-1}+c\right) \bmod m
$$

where $Z_{i}$ is a series of random number n-th, $Z_{i-1}$ is a previous random number, $a$ is multiplier factor, $c$ is a constant and $m$ is modulo. The algorithm to generate standardized normal data with Box-Muller transformation as follows. 
1. Generate $U_{1}$ and $U_{2}$ from $U(0,1)$.

2. Determine

$$
\begin{gathered}
Z_{1}=\left(-2 \ln U_{1}\right)^{\frac{1}{2}} \cos \left(2 \pi U_{2}\right), \text { or } \\
Z_{2}=\left(-2 \ln U_{1}\right)^{\frac{1}{2}} \cos \left(2 \pi U_{2}\right)
\end{gathered}
$$

3. So $Z_{1}, Z_{2}$ are random number from $U(0,1)$.

a. Generate $Z$ from $N(0,1)$ in the previous algorithm.

b. Determine $X=\sigma Z+\mu$.

To generate number with Weibull distribution can be calculated with formula $X=\beta(-\ln U)^{\frac{1}{\alpha}}$ [5]. Probabilistic Economic Order Quantity (EOQ) model is a method that is used to determine when an order will be done and the quantity of goods in each order to minimize value of total cost. The following are steps to determine $\mathrm{Q}$ and $\mathrm{R}$.

1. Calculate $\mathrm{Q}$ when $\mathrm{E}(\mathrm{M}>\mathrm{R})=0$, so that $\mathrm{Q}$ can be calculated with formula:

$$
Q=\sqrt{\frac{2 A D}{H}}
$$

where $\mathrm{Q}$ is quantity in unit, D is average of demand in year in unit and $\mathrm{A}$ is cost of order.

2. Determine $\mathrm{P}(\mathrm{M}>\mathrm{R})$ and $\mathrm{R}$ using $\mathrm{Q}$

$$
P(M>R)=\frac{H Q}{K D}
$$

with $\mathrm{R}=\bar{M}+S$.

3. Determine $\mathrm{E}(\mathrm{M}>\mathrm{R})$ using $\mathrm{R}$

$$
E(M>R)=\sum_{M=R+1}^{M_{\max }}(M-R) P(M)
$$

4. Redetermine $Q$ with $E(M>R)$ as $Q^{*}$

$$
Q^{*}=\sqrt{\frac{2 D[A \times K \times E(M>R)]}{H}}
$$

After obtaining $Q^{*}$, the next step performs iteration at step (2), (3) and (4) until Q and R are same.

Data that will be disucessed is demand, cost, and lead time [6]. The calculation is performed with numerical calculation using probabilistic EOQ model and will be simulated using Monte Carlo simulation so that is obtained optimal solution of supply in the future.

\section{Analysis and Discussion}

The following table is data of demand of shoes. 
Table 1 Data of Demand

\begin{tabular}{ccc}
\hline No & Period & Demand \\
\hline 1 & October, 2012 & 667 \\
\hline 2 & November, 2012 & 653 \\
\hline 3 & December, 2012 & 837 \\
\hline 4 & January, 2013 & 576 \\
\hline 5 & February, 2013 & 683 \\
\hline 6 & March, 2013 & 362 \\
\hline 7 & April, 2013 & 162 \\
\hline 8 & May, 2013 & 563 \\
\hline 9 & June, 2013 & 435 \\
\hline 10 & July, 2013 & 774 \\
\hline 11 & Agustus, 2013 & 476 \\
\hline 12 & September, 2013 & 381 \\
\hline 13 & October, 2013 & 707 \\
\hline 14 & November, 2013 & 847 \\
\hline 15 & December, 2013 & 559 \\
\hline 16 & January, 2014 & 578 \\
\hline 17 & February, 2014 & 896 \\
\hline 18 & March, 2014 & 838 \\
\hline 19 & April, 2014 & 773 \\
\hline 20 & May, 2014 & 742 \\
\hline 21 & June, 2014 & 644 \\
\hline 22 & July, 2014 & 745 \\
\hline 23 & Agustus, 2014 & 869 \\
\hline & Total & 14767 \\
\hline & Average & 642043 \\
\hline & &
\end{tabular}

Meanwhile, data of cost that is needed to make shoes consist of price per-unit (P), cost of order (A), cost of saving $(\mathrm{H})$ and cost of lack $(\mathrm{K})$ per-year.

Table 2 Data of Cost

\begin{tabular}{ccccc}
\hline Product & Purchase Price $(\$)$ & Purchase Order $(\$)$ & Save Cost $(\$)$ & Shortage Cost (\$) \\
\hline Shoes & 29,32 & 18,21 & 3,76 & 5 \\
\hline
\end{tabular}

Table 3 Lead Time

\begin{tabular}{ccc}
\hline Product & per-Month & per-Year \\
\hline Shoes & 3 & $\frac{1}{4}$ \\
\hline
\end{tabular}

Based on calculation above, to obtain total of supply cost from demand of shoes can be determined with probabilistic EOQ supply model. After calculating the value of optimal order measure with several iteration, the following is a summary of calculation result $\mathrm{Q}, \mathrm{P}(\mathrm{M}>\mathrm{R}), \mathrm{R}$ and $\mathrm{E}(\mathrm{M}>\mathrm{R})$. 
Table 4 Calculation of $\mathrm{Q}, \mathrm{R}, \mathrm{P}(\mathrm{M}>\mathrm{R})$ and $\mathrm{E}(\mathrm{M}>\mathrm{R})$

\begin{tabular}{ccccc}
\hline Iteration & $\mathrm{Q}$ (Unit) & $\mathrm{P}(\mathrm{M}>\mathrm{R})$ & $\mathrm{R}($ Unit $)$ & $\mathrm{E}(\mathrm{M}>\mathrm{R})$ \\
\hline 1 & 378 & 0.0192 & 2445 & 5.9047 \\
\hline 2 & 613 & 0.0312 & 2406 & 9.619 \\
\hline 3 & 722 & 0.0367 & 2388 & 11.333 \\
\hline 4 & 767 & 0.039 & 2381 & 11.999 \\
\hline 5 & 784 & 0.039 & 2381 & 11.999 \\
\hline 6 & 784 & 0.039 & 2381 & 11.999 \\
\hline
\end{tabular}

Based on Table 4 shows that the number of $\mathrm{Q}$ and $\mathrm{R}$ in several iteration have been done to obtain same value. The value of optimal demand (Q) is 784 unit and the return demand point (R) is 2381 unit. Using MATLAB R2017a is obtained curve of probability density function of demand as follow.

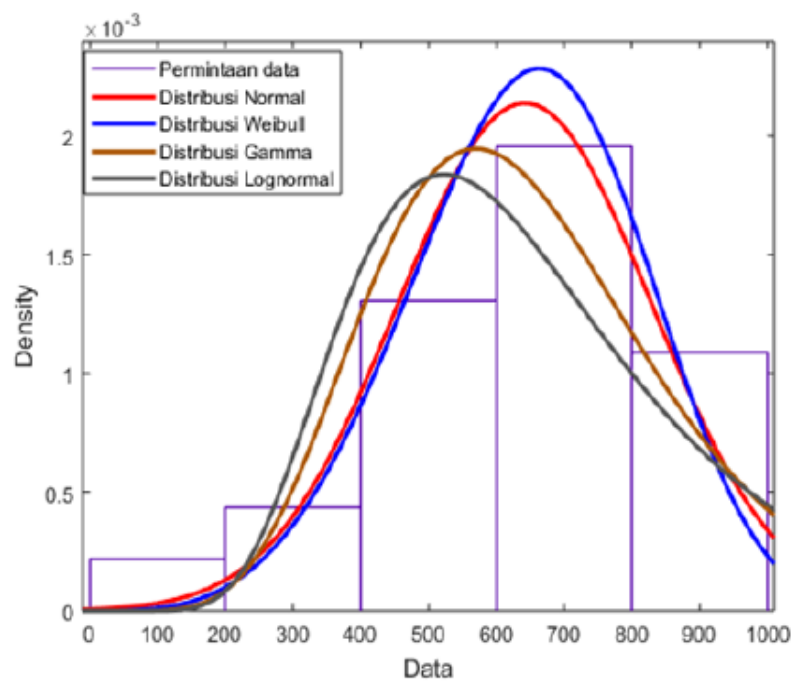

Figure 1 Distribution Fitting PDF

Based on the Figure 1 the demand data more approach to Normal dan Weibull distribution rather than Gamma and Lognormal distribution. The value of log likelihood normal distribution and Weibull is $-152,39$ and $-151,988$, rather than log likelihood of Gamma and lognormal 155,304 and $-157,83$. So demand data more approach to Normal and Weibull distribution.

\section{Conclusion}

This research designs a simulation to control the inventory with number of demand that is probabilistic. The calculation is conducted with numerical calculation using probabilistic EOQ model and Monte Carlo simulation. Based on calculation, the inventory cost total using probabilistic EOQ model is $\$ 486128,195$. After simulation using Monte Carlo simulation where data of demand follows normal distribution and obtained the total of supply cost is $\$ 461116,05$ in 23 months, where data of demand using Weibull distribution obtained total of supply cost is $\$ 482301,76$. So that can be summarized that Monte Carlo simulation can calculate the supply of 
optimal probabilistic in the future knowing the probability distribution following data of demand.

\section{REFERENCES}

[1] R. Y. Rubinstein and D. Kroese, Simulation and the Monte Carlo Method, New York: John Wiley \& Sons, 1981.

[2] S. Vita, "Sains Manajemen," in Introduction to Management Science, 8th Ed., Jakarta: Salemba Empat (in Indonesian), 2001.

[3] B. S. Djati, Simulasi: Teori dan Aplikasinya, Yogyakarta: Andi Publisher, 2007.

[4] B. Render, R. M. Stair Jr and M. E. Hanna, Quantitative Analysis for Management, New Jersey: Pearson Education Inc., 2012.

[5] A. M. Law and W. D. Kelton, Simulation Modelling and Analysis, USA: Mcgraw-hill, 2000.

[6] B. Wenda, H. Adianto and Rispianda, "Usulan Pemesanan Sepatu Keselamatan dengan Model Economic Order Quantity (Studi Kasus di PT. X)," Jurnal Online Institut Teknologi Nasional, vol. 3, no. 1, pp. 182-183, 2015.

[7] H. A. Taha, Operations Research: An Introduction, 8th Ed., USA: Prentice Hall, 2007.

[8] Basuki, "Optimasi Ukuran Lot Pemesanan yang Ekonomis pada Permintaan Deterministik Dinamis menggunakan Metode Heuristik Silver-Meal di PT. XYZ," Jurnal Citra Widya Edukasi, vol. 7, no. 2, pp. 13-20, 2015.

[9] R. J. Tersine, Principles of Inventory and Materials Management, 4th Ed., USA: Prentice Hall, Inc., 1994.

[10] R. D. Kusdian, A. S. Ridwan, O. Z. Tamin and A. Syafruddin, "Penggunaan Distribusi Normal dalam Memodelkan Sebaran Persepsi Biaya Perjalanan dan Transformasi BoxMuller pada Pengambilan Sampel Acak Model Pemilihan Rute dan Pembebanan Stokastik," Jurnal Transportasi, vol. 5, no.2, pp. 128-131, 2005. 